\title{
The concept of revelation in terms of the evolution of consciousness
}

\begin{tabular}{|c|c|}
\hline $\begin{array}{l}\text { Author: } \\
\text { Klaus Nürnber }\end{array}$ & $\operatorname{ger}^{1}$ \\
\hline $\begin{array}{l}\text { Affiliation: } \\
\text { }{ }^{\text {Department }} \\
\text { Christian Ethic } \\
\text { Theology, Uni } \\
\text { Pretoria, Sout }\end{array}$ & $\begin{array}{l}\text { Dogmatics and } \\
\text { s, Faculty of } \\
\text { rersity of } \\
\text { h Africa }\end{array}$ \\
\hline $\begin{array}{l}\text { Project leade } \\
\text { Project numb }\end{array}$ & $\begin{array}{l}\text { J. Buitendag } \\
\text { er: } 02402343\end{array}$ \\
\hline $\begin{array}{l}\text { Description: } \\
\text { Prof. Dr Klaus } \\
\text { part of the res } \\
\text { 'Theology of N } \\
\text { by Prof. Dr Joh } \\
\text { (Dean, Faculty } \\
\text { Department D } \\
\text { Christian Ethic } \\
\text { Theology, Uni } \\
\text { Pretoria. }\end{array}$ & $\begin{array}{l}\text { Nürnberger is } \\
\text { earch project, } \\
\text { lature', directed } \\
\text { lan Buitendag } \\
\text { of Theology), } \\
\text { ogmatics and } \\
\text { s, Faculty of } \\
\text { lersity of }\end{array}$ \\
\hline $\begin{array}{l}\text { Correspondin } \\
\text { Klaus Nürnber } \\
\text { info@ @klaus-nu }\end{array}$ & $\begin{array}{l}\text { g author: } \\
\text { ger, } \\
\text { irnberger.com }\end{array}$ \\
\hline $\begin{array}{l}\text { Dates: } \\
\text { Received: } 11 \mathrm{~A} \\
\text { Accepted: } 31 \\
\text { Published: } 02\end{array}$ & $\begin{array}{l}\text { pr. } 2016 \\
\text { uly } 2016 \\
\text { Dec. } 2016\end{array}$ \\
\hline $\begin{array}{l}\text { How to cite th } \\
\text { Nürnberger, K } \\
\text { concept of rev } \\
\text { terms of the e } \\
\text { consciousness } \\
\text { Teologiese Stu } \\
\text { Theological St } \\
\text { a3430. http:// } \\
\text { org/10.4102/ }\end{array}$ & $\begin{array}{l}\text { is article: } \\
\text {, 2016, 'The } \\
\text { elation in } \\
\text { volution of } \\
\text {, HTS } \\
\text { dies/ } \\
\text { udies 72(4), } \\
\text { dx.doi. } \\
\text { ts.v72i4-3430 }\end{array}$ \\
\hline $\begin{array}{l}\text { Copyright: } \\
\text { C 2016. The A } \\
\text { Licensee: AOSI } \\
\text { is licensed und } \\
\text { Creative Comn } \\
\text { Attribution Lic }\end{array}$ & $\begin{array}{l}\text { uthors. } \\
\text { S. This work } \\
\text { ler the } \\
\text { nons } \\
\text { ense. }\end{array}$ \\
\hline Read online: & \\
\hline 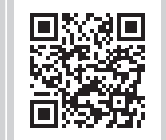 & $\begin{array}{l}\text { Scan this QR } \\
\text { code with your } \\
\text { smart phone or } \\
\text { mobile device } \\
\text { to read online. }\end{array}$ \\
\hline
\end{tabular}

Following Paul's injunction in 1 Corinthians 9:19-23 we have to 'become scientists' to a scientifically informed audience. While theology cannot agree with the naturalist denial of transcendence, it can adopt the experiential-realist approach typical for the sciences in its description of the Christian faith as an immanent part of cosmic evolution, albeit at a higher level of emergence. The article begins with my understanding of evolutionary theory (big bang cosmology, entropy, emergence, neural networks as infrastructure of consciousness, evolution and differentiation, sequences of past, present and future, contingency etc.) It then describes God consciousness as the intuition, perception or conceptualisation of the transcendent Source and Destiny of experienced reality and locates God consciousness in the evolutionary process. Biblical God consciousness displays two distinct characteristics: God's creative power is experienced in reality, while God's benevolent intentionality is proclaimed on the basis of a religious tradition. The evolutionary trajectory of biblical God consciousness, culminating in the Christ-event, is sketched and the God consciousness of Jesus is deduced from its religious embeddedness, its social-environmental relationships and its religious impact. Implications of an experiential-realist approach are (1) a dynamic, rather than ontological Christology and (2) the cosmic significance of the sacrifice of God in Christ. On this basis revelation is described first in experiential-realist and then in theological terms. The tension between the experience of God's creative power and the proclamation of God's benevolence leads to a dynamic, rather than ontological rendering of the Trinity. Finally, traditional eschatological assumptions are reconceptualised as God's dynamic vision of comprehensive well-being operating like a horizon that moves on as we approach it and displays ever new vistas, challenges and opportunities.

\section{Introduction}

This article approaches the concept of 'revelation in Christ' from a consistently experiential-realist point of view and works within an evolutionary paradigm. My motivation for this approach is derived from Paul's missionary principle of 'becoming a Jew to the Jews and all things to all people' thus addressing the various groups that he encountered within their particular sets of assumptions (1 Cor 9:19-23). By implication, the contemporary theologian must 'become a scientist to a scientist' so as to restore the plausibility and credibility of a message couched in a pre-scientific idiom for an audience informed by modern science.

An experiential-realist point of view remains in the sphere of immanent experience and avoids references to 'supernatural events', metaphysical edifices, reified abstractions and metaphors, fantasy and wishful thinking. ${ }^{1}$ But it does include mental constructs based on synaptic networks in its concept of experienced reality. ${ }^{2}$ When I speak of the evolution of consciousness, I do not refer

1.My approach is similar to that of 'critical realism' (Peacocke 2007:5-11; Polkinghorne 1996:11-25), although I think I am more
consistent. Polkinghorne, for instance, argues that 'No naive objectivity is involved in either discipline; both science and theology speak
of entities not directly observable to us' and he mentions quarks and gluons (Polkinghorne 1996:14). He does not seem to make a
difference between immanent transcendence (aspects of immanent reality not directly accessible to experience) and transcendent
immanence (the divine as Source and Destiny of immanent reality). See Nürnberger (2011:149-160). Peacocke believes that with the
incarnation a 'new ontology is inaugurated' (Peacocke 2007:37), which I believe to be an invalid application of scientific assumptions
on religious certainties. Similarly, Russel believes that the resurrection of Christ might be the 'first instantiation' of 'a new law of nature',
which in the coming New Creation 'will become a general, regular phenomenon' (Russell 2008:309-310). Experiential realists will be
hard pressed to consider that as a serious option (Nürnberger 2012:970-978). In general, I do not believe in the comparability of
science and theology on the grounds of their respective formal rationalities, a stance that brackets the fact that a religious certainty is
essentially different from a scientific model. In epistemological terms, my experiential-realist approach is similar to 'model-dependent
realism' (Hawking \& Mlodinow 2010:7-8). Obviously I do not subscribe to the naturalistic reductionism of the latter. For a fully
developed argument, see Nürnberger (2016:45-71).

2.'(An) ontological reality must be assigned to thoughts, emotions, and social human constructions because of their ability to have causal effects on the physical world' (Ellis 2008:67). A profound palaeontologically based analysis of the indissoluble interaction between biological, spiritual and social phenomena is offered by Smail (2008).

Note: Original Research: Volume 17 in the South African Science and Religion Forum Series, edited by Prof. Dr Cornel du Toit (UNISA) and Prof. Dr Danie Veldsman, entitled 'Creation, Consciousness and Christology: Evolutionary Perspectives', Proceedings of the 20th conference of the South African Science and Religion Forum (SASRF) of the Research Institute for Theology and Religion held at the University of South Africa, Pretoria 16-18 September 2015. 
to the evolution of the general human capacity of being conscious of self and the environment, but to the particular content of such a consciousness, in this case the God consciousness found in the Christian faith.

The article synthesises my responses to a wide range of scientific and theological debates. Not to water down the stringency of the argument, I retained the concise formulations of the original presentation as far as possible and kept references to historical or contemporary scholarly debates to a minimum. Where they do occur, they are meant to be pointers to these debates, rather than sources used. Where applicable, I drew out the implications of my statements for adjacent theological issues, notably Christology, the Trinity and eschatology. The argument proceeds as follows:

1. My understanding of the theory of evolution.

2. The evolutionary nature of God consciousness.

3. The emergence, evolution and differentiation of biblical God consciousness

4. The God consciousness of Jesus of Nazareth and his followers.

5. Revelation in experiential-realist terms.

6. Revelation in theological terms.

7. Implications for Christology, Trinity and Eschatology.

\section{My understanding of the Theory of Evolution}

Big bang cosmology: departing from a singularity in which all cosmic energy was concentrated in a minute point (or alternatively, minute initial vibrations led to an exponentially growing proliferation of energy), the development of ever greater and more complex forms of reality occurred over vast stretches of time. ${ }^{3}$

This implies that there is only one all-inclusive immanent reality. However, while naturalism assumes that 'nature' is all there is and ever has been, that reality is closed in upon itself and that cosmic evolution is self-generated, selfsustaining, and self-destructive, the Judeo-Christian faith assumes that immanent reality is open towards a transcendent Source and Destiny. ${ }^{4}$

Entropy: Cosmic evolution happens in the context of entropic dissolution where potent energy changes into spent energy, compaction into dissipation, order into disorder. ${ }^{5}$ The entropic process provides the energy without which structured reality could not evolve and function. By implication, 'natural evil', such as erosion, deterioration, destruction, death and decomposition, is built into the system.

3.For a differentiated but accessible discussion of the theory see, for instance, Greene (2005:272-303).

4.For a detailed argument, see Nürnberger (2011:148-193).

5.The second law of thermodynamics is the origin of the theory of entropy, but it has since proved to be of exceptional explanatory power in almost all spheres of life. Following a perceptive economist, I have applied it to the growing discrepancies in life chances in the modern world (Nürnberger 1999:333-357), and even to the evolution of the biblical tradition (Nürnberger 2002:79-82).
Emergence: evolution takes place through increasing levels of complexity, caused by ever new relationships between components that produce ever greater integrated wholes. Wholes present a higher level of emergence that is different from the sum total of their components. Each level has its own regularities and (exponentially more numerous) contingencies. The hierarchy of emergences covers all of reality from subatomic levels to consciousness and social structures and processes. ${ }^{6}$ Figure 1 gives a crude indication of subsequent levels in the hierarchy of emergences.

Synaptic networks: Connections between neurons in the brain (leading to a virtually unlimited number of potential brain states) form the infrastructure of patterns of consciousness, that is, the personal or 'spiritual' level of reality.? Communication networks between individual patterns of consciousness through symbolic representation (notably language) lead to the evolution of collective consciousness, which is a new emergent reality with its own characteristics, regularities and contingencies. ${ }^{8}$

Bifurcation: a process splits within the same environmental niche. This happens when the forces that impact a situation

\begin{tabular}{|c|c|}
\hline EMERGENCE = & SOCIETAL PROCESSES \\
\hline \multicolumn{2}{|l|}{ EXPONENTIALLY INCREASING } \\
\hline \multirow{2}{*}{$\begin{array}{l}\text { COMPLEXITY OF RELATIONSHIPS, } \\
\text { REGULARITIES AND CONTINGENCY }\end{array}$} & STRUCTURED CONSCIOUSNESS \\
\hline & SYNAPTIC NETWORKS \\
\hline \multicolumn{2}{|c|}{ ORGANISMS } \\
\hline NEWTONIAN & \\
\hline SUBATOMIC LEVELS & \\
\hline
\end{tabular}

Source: Author's own work

FIGURE 1: Levels of emergence.

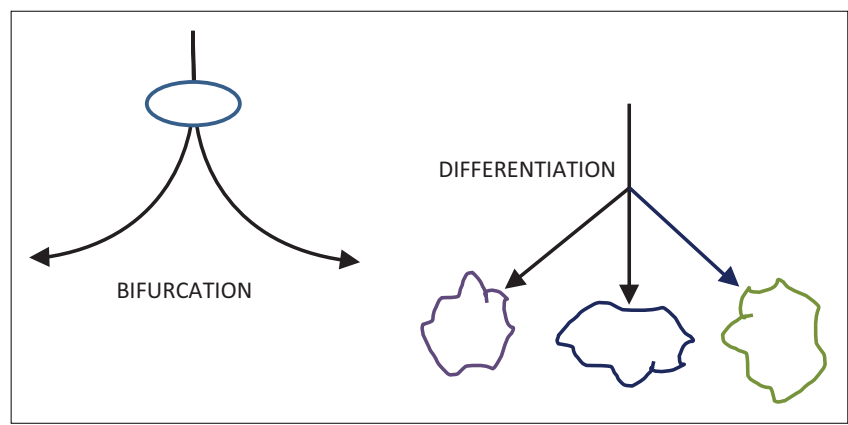

Source: Author's own work

FIGURE 2: Bifurcation and differentiation.

6.For the theory of emergence, see Clayton (2006:65-148). Kauffman (2008) provides us with a fascinating mathematical treatment of emergence that refutes physical reductionism. Similarly Ellis (2008:57-82). For complexity theory see Mitchell (2009:94-111).

7.Clayton (2006:107-155) shows how difficult it is to come to grips with the relation between brain states (or rather processes) and consciousness, but this is typical for higher levels of emergence. Nowhere in his argument is it doubted that neurological networks and process form the infrastructure of consciousness.

8.For the functioning brain see https://en.wikipedia.org/wiki/Neuron. For synaptic networks see https://en.wikipedia.org/wiki/Synapse. 
are so finely balanced that the process can move in any direction, thus also in more than one direction at the same time (the image of identical twins). Differentiation: entities with differing mutations and/or pre-adaptations flourish or deteriorate in differing environmental niches. Niches open up, grow, diminish, or close down due to pressures from competing niches.

The dynamics of time: Processes move from factuality (what has become) via actuality (what is in the process of becoming) towards potentiality (what may become). They move within particular parameters, which depend on the powers built up in the past, which impact the current situation and which follow certain regularities and contingencies. ${ }^{9}$

An open future: the past trajectory of a process opens up a real but limited spectrum of possibilities, from the possible about to be realised, to the adjacent possible, stages of more remote possible and up to the impossible. This depends on the relative strength of all powers that impact a situation. ${ }^{10}$

Contingency: If the forces and regularities impacting a particular situation are sufficiently balanced, an additional impact can change the direction of the process. At such points sensitivity of initial conditions can lead to exponentially diverging trajectories of an evolutionary process. ${ }^{11}$ Contingency obtains only in particular situations and in differing degrees, therefore, rather than determining the entire cosmic process that emanated from the big bang. ${ }^{12}$

Intentionality and agency are located at the personal (spiritual) level of emergence and only there. Their effective operation presupposes a situation where the powers impacting the initial conditions of a situation are sufficiently balanced for an additional force to be able to redirect the process. Intentionality is the motivational force that focuses the

\footnotetext{
9.It is inappropriate, therefore, to attribute power to the future, which is pure potentiality, or to speculate that future power, deemed divine, is the creative force that underlies the dynamic evolution of reality. 'Aristotle's doctrine of entelechies, for example - of future, and thus merely potential, patterns pulling natural for example - of future, and thus merely potential, patterns pulling natural
processes towards themselves - is incompatible with natural science ...' (Clayton processes towards themselves - is incompatible with natural science ... (Clayton
$2006: 139$ ). Visions, in contrast, motivate humans to move forward from the 2006:139). Visions, in contrast, motivate humans to move forward from the
present to a desired future. For an application see my critique of an article by Wolfhart Pannenberg in this regard (Nürnberger 2011:298, footnote 114).

10.Note that Kauffman (2008) uses the term 'adjacent possible' for the next possible step in the evolutionary and emergent sequence of potentialities, while I am using the term for what could become reality if the powers that impact a situation were slightly different.

11.For the concept of 'sensitivity to initial conditions' see https://en.wikipedia.org/ wiki/Chaos theory. Chaos theory explores deterministic but unpredictable processes in mathematical terms. Unpredictability does not imply a lack of regularity, but only a complexity that is beyond the capacity of current mathematics to master. I am using the term as a pointer to the concept of an 'open future' (based on the variability and malleability of initial conditions) as well as the (based on the variability and malleability of initial conditions) as well as the potential of evolutionary processes to accelerate exponentially. Moreover, at the
spiritual level of emergence, the occurrences of contingency reach proportions that vastly increase the spectrum of potentialities.

12.One cannot restrict divine creative action at the beginning (creatio ex nihilo) or during the process (creatio continua) to contingency. Given a different set of initial conditions, our universe could perhaps have evolved in a totally different direction, but whether such a different set would have been possible, or whether the universe could just as well have not existed at all, lies beyond our observation and imagination. Nor is it true that the current cosmic process, once started, is imagination. Nor is it true that the current cosmic process, once started, is contingent in all its aspects. This claim rests on the metaphysical or doctrinal assumption that God is not subject to constraints and can intervene whenever and however he divine action to the (untenable ' the (untenable) 'God of the gaps' (cf. Gregersen 2008:179-199). One should also not confuse contingency with probability. Wherever there is probability, there must be some kind of regularity; otherwise it would be pure chance.
}

attention of the human being on a value deemed valid, a goal deemed desirable or a vision deemed salutary. Agency is the application of additional power influencing the direction of a process that otherwise would follow a trajectory of least resistance.

By implication, freedom of the will is real, rather than illusory. However, it is restricted to particular parameters set by the past and constraints determined by the constellation of powers that impact a situation. Its operation presupposes undetermined or underdetermined situations. ${ }^{13}$

\section{The evolutionary nature of God consciousness $^{14}$}

'God' is our name for the intuition, perception or concept of a transcendent Source and Destiny of reality as a whole. Theology is not dealing with God 'as such', therefore, but our unarticulated intuition, uncritical perception, or conceptualised notion of God. All forms of consciousness, including God consciousness, are part of cosmic evolution. They emerge, evolve, persist, deteriorate and disintegrate in time and space. They are neither static, nor eternal, nor perfect, but fallible and malleable, otherwise theology would not make sense. The task of theology is to find the most appropriate concept of God in terms of a particular tradition under a particular set of circumstances.

As the Source of reality, God is 'present' and 'active' in all of reality. ${ }^{15}$ But being transcendent, God cannot be real in the sense that calcium, cats or synaptic networks are real. God cannot be part of immanent reality among other parts, with whom 'he' could compete or cooperate at the same level of causation. Rather, God works through all these entities and processes as their transcendent Source and Destiny.

World consciousness (environment) and God consciousness (intuition of a transcendent Source and Destiny of reality) are occasioned by experiences of derivation, dependence,

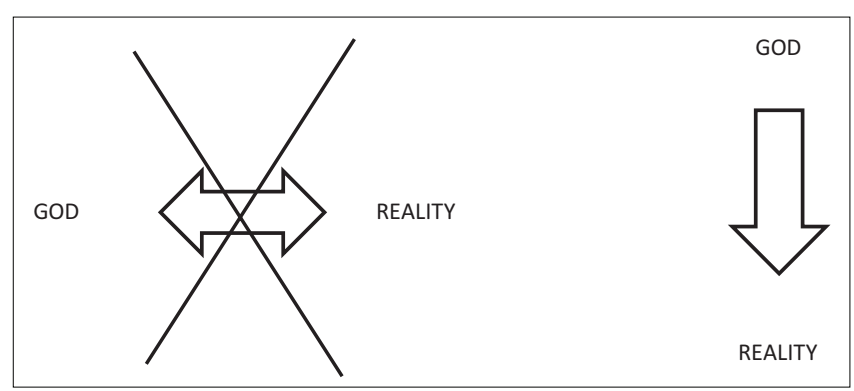

Source: Author's own work

FIGURE 3: The verticality of God's relationship to reality.

13.For my take on the freedom of the will, see Nürnberger (2011:133-135).

14.In what follows, I largely draw on my previous work (Nürnberger 2011, 2013) because it condenses my responses to theological debates over many decades. Specific references would be selective and arbitrary.

15. In contrast to 'immanent transcendence' (referring to aspects of immanent reality that are not immediately accessible, such as the past, the future, etc.), one can speak of 'transcendent immanence' (referring to the fact that experienced reality is not closed in upon itself, but open to a transcendent Source) 
vulnerability, mortality and accountability. Perceptions of the ultimate essence, foundation or source of reality can take many forms: a functioning mechanism, a multi-verse, a blind fate, a dialectical process, a cruel tyrant, a demanding law giver, a merciful father, or whatever. ${ }^{16}$

God consciousness is a dynamic phenomenon that emerges, evolves, and differentiates in human history. Mutations and pre-adaptations respond to, and flourish in, proliferating niches leading to multiple religious traditions. They compete with each other, merge with each other, augment each other, and replace each other.

The personal God: Intentionality and agency occur at the emergent level of structured and oriented consciousness and only there, although networks of upward and downward causation lead to multiple feedback loops throughout the system. The theory of emergence implies that God became a person for humans because humans are persons, an implication born out by the virtually universal rendering of the divine in anthropomorphic metaphors. Figure 4 depicts the location of intentionality and agency in the hierarchy of emergences.

However, intuited as the Source and Destiny of reality as a whole, including all levels of emergences, God must be much more than a person, just as humans are much more than persons, namely particles, molecules, bio-chemical processes, brains and so forth. ${ }^{17}$ That God is more than a person manifests itself in the biblical intuition that God is the ultimate where from and where to of the whole of reality, including both beneficial and detrimental experiences. ${ }^{18}$

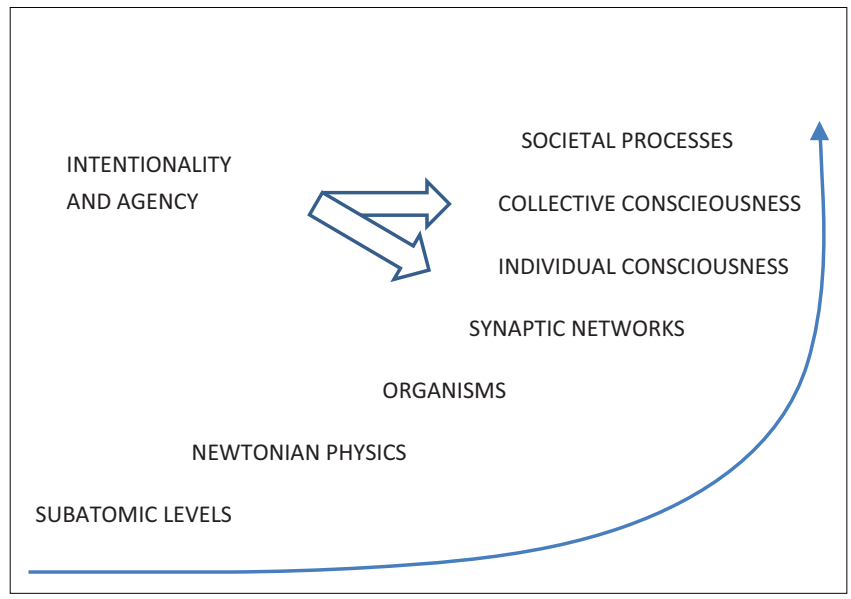

Source: Author's own work

FIGURE 4: Intentionality and agency within the hierarchy of emergences.

16.Going to more superficial and mundane levels, anything to which we entrust ourselves, from which we expect life, prosperity, fulfilment or satisfaction, which fascinates, enslaves and drives us, is our 'god' (see Martin Luther's explanation of the First Commandment in his Large Catechism; Tappert 1959:365-368).

17.For detail, see Nürnberger (2013:120-129).

18.The limitation of God as Source of reality to whatever seems to be desirable or beneficial to the exclusion of the undesirable and detrimental leads to a truncated (and unbiblical) concept of God. The New Testament witness to the unconditional benevolence of God is a faith statement maintained in the face of disagreeable and detrimental experiences.
Biblical God consciousness thus includes two fundamental aspects:

1. The creative power attributed to the transcendent Source and Destiny of actually experienced reality can be observed and understood in principle and is explored by the sciences. ${ }^{19}$ In this sense God is active 'everywhere' and 'all the time' (creatio continua). ${ }^{20}$ The reality we experience is highly ambivalent; it does not reveal any meaning, purpose or goal - except that particular antecedents, conditions and constellations form prerequisites for subsequent states to materialise. A fatal accident, for instance, has causes that can be understood, but no observable predetermined purpose or meaning.

An experiential-realist perspective will abandon a metaphysical concept of 'omnipotence' which assumes that divine intentionality and power are unrestricted by definition. Such a concept represents an assertion that cannot be substantiated experientially. It is based on an idealised abstraction from the experience of power in its multiple forms. Constraints are, in fact, built into the world we know.

In contrast, the experiential concept of omnipotence attributes the energy underlying actual structures and processes, which operate according to regularities and contingencies, to God the Creator. Constraints experienced in reality are necessary because without them reality could not exist or function. In this sense they can be attributed in anthropomorphic terms to divine benevolence. ${ }^{21}$

2. The benevolent intentionality of the Source and Destiny of reality is not experienced but proclaimed on the basis of a particular religious tradition, which is a part of cosmic evolution among others. This proclamation speaks in the authority of God, the ultimate Source and Destiny of reality. For the believer it operates as the human medium of God's self-communication to humanity, albeit in a broken and provisional form. Forming particular synaptic networks in the brain, it can be rejected, corrected, augmented, transformed or appropriated. Figure 5 depicts the dialectical nature of biblical God consciousness.

19.Theology cannot possibly know better and should get its clues from the sciences, albeit in a critical way. It should, for instance, expose the absolutisation of the local, relative and temporal, which is idolatry.

20.The concept of creation out of nothing (creatio ex nihilo) is not derived either from the two main biblical creation stories, or the many allusions to creation in DeuteroIsaiah, the Psalms, Job, Wisdom literature, and so on. In Gen 2 God moulds a structure out of formless matter; in Gen 1 God overcomes unstructured chaos (darkness, the primeval ocean) by divine decree. In both cases the authors are not interested in the metaphysical question of what was there before creation. In Paul the focus is on the discontinuity between an unauthentic and an authentic way of being human. The doctrine of 'creation out of nothing' is rooted in Hellenistic metaphysics, where the divine is conceptualised as the epitome of ultimate perfection, which implies, among other things, eternity, universality, omnipotence, omniscience, and absolute sovereignty.

21.According to the biblical witness, it is God's benevolence that sets up dependable structures and initiates redemptive processes (Gen 1). The biblical witness also structures and initiates redemptive processes (Gen 1 ). The biblical witness also not the limitations of God, but that does not imply that God would want to suspend cosmic regularities to meet our petty needs. It could imply, however, that God cosmic regularities to meet our petty needs. It could imply, however, that God
knows the full range of potentialities that any present situation opens up and might guide our lives in beneficial directions. 


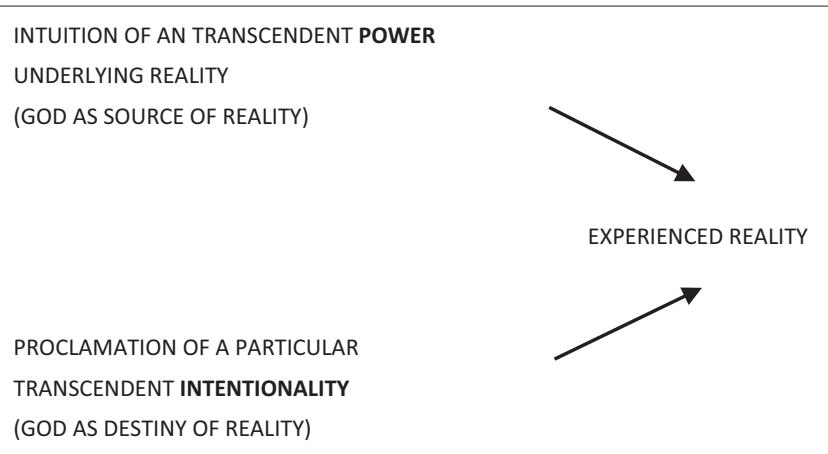

Source: Author's own work

FIGURE 5: The two dimensions of God consciousness.

\section{The emergence, evolution and differentiation of biblical God consciousness}

The biblical faith emerged from Ancient Near Eastern precedents in humble forms that evolved and differentiated into an increasing number of variants over a time span of anything between one and two millennia. Its trajectory can be understood as a series of redemptive responses to ever new situations of need and alternative worldviews, a process where collective memories of previous 'great acts of God' were applied to changed situations, thus leading to the evolutionary trajectory of a living tradition. Figure 6 is a crude depiction of some of the more important stages in this process. Note that previous stages were not replaced by subsequent ones but integrated in new wholes with the latter.

By the time of Jesus, Jewish traditions had proliferated into a variety of forms: priestly, prophetic, rabbinic, messianic, mystic, wisdom-based, apocalyptic, and revolutionary. The emergence of the God consciousness of Jesus has to be seen against the background of this proliferation. Figure 7 gives some indication of the network of Jewish traditions and how they ushered in the two main Christian versions of the biblical faith.

\section{The God consciousness of Jesus of Nazareth and his followers}

What can we know of the God consciousness of Jesus? Nothing at all, apart from its historical manifestations:

1. The embeddedness of Jesus in the Israelite-Jewish religious and cultural traditions. These include the covenant and law tradition, the messianic tradition, and the apocalyptic tradition.

2. The typical clientele of Jesus: this includes the incurably sick, handicapped, demon possessed, outcasts, public sinners, women and children - thus the marginalised sections of society.

3. The kind of followers: his disciples and sympathisers hailed from various professions and fairly contrasting backgrounds.

4. The kind of adversary: The conflict between Jesus and the rabbinic and pharisaic representatives of the torah (the Law of Moses) on the one hand, and the priestly

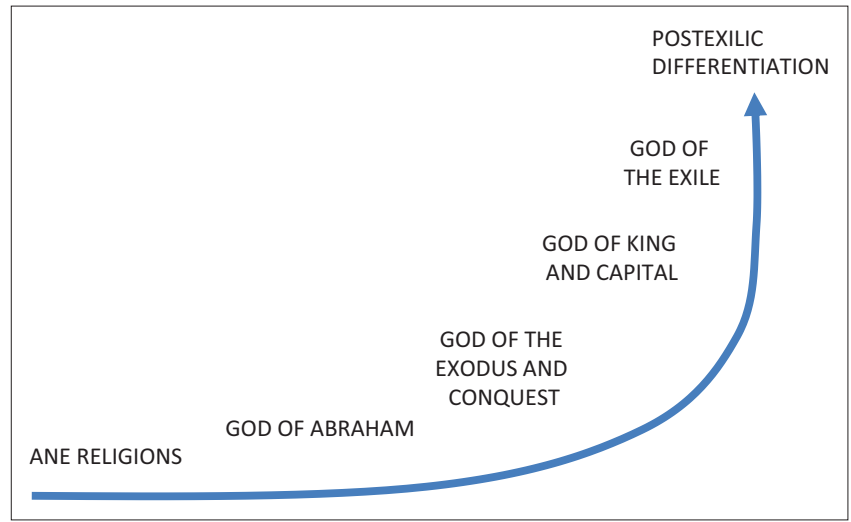

Source: Author's own work

FIGURE 6: Emergence and evolution of Israelite God consciousness.

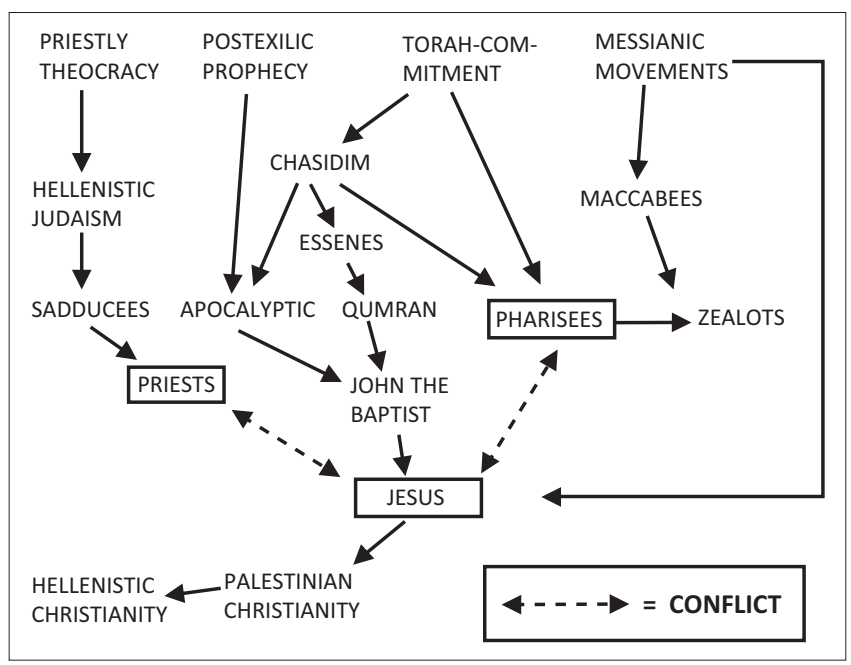

Source: Author's own work

FIGURE 7: Postexilic differentiation of Jewish God consciousness.

establishment on the other led to his condemnation. The perceived or construed conflict between Jesus' messianic action and the Roman imperial authorities led to his crucifixion. ${ }^{22}$

5. The consequences (Wirkungsgeschichte): These include the initial conflict and eventual permanent split between the nascent Palestinian Christianity and rabbinic Judaism after the Jewish war; the conceptualisations of Jesus' proclamation and enactment of God's redeeming love as the messianic representative of God by the Christian community, and the reception of the message of God's unconditional acceptance of the unacceptable in the Hellenistic world.

\section{The God consciousness of Jesus in evolutionary terms}

The pivotal points at issue between Jesus and his adversaries can be formulated as (1) God's suffering, transforming acceptance of the unacceptable, rather than the devastating judgment of pagans and godless Jews expected by Judaism, (2) which Jesus proclaimed and enacted in the authority of 22. For my reconstruction of the historical "Christ-event' and its implications, see Nürnberger (2013:180-184, 2016:171-229). 
the messianic representative of God on earth, in contrast with a messiah expected to act in holistic socio-political terms. The Apostle Paul, followed by Luke and John, drew out the notion of God's unconditional acceptance to include nonIsraelites, replacing literal adherence to the Law of Moses with involvement in the redeeming love of God in Christ.

The God consciousness of Jesus as a God of redeeming love acting through his messianic representative had antecedents in the Israelite-Jewish tradition, although Jesus may have emphasised and radicalised these traditions. It concerned the character of both the assumed self-disclosure of a God of love and the authority of the medium of this self-disclosure:

1. The notion that Yahweh, the God of Israel, was a strict, but merciful God, committed to Israel, God's people, can be found all over the Old Testament: the Pentateuch, the Psalms, the prophets. Here and there the awareness dawned that Israel was chosen to be the witness of Yahweh and his righteousness to the rest of humanity. However, the notion of a covenant between Yahweh and Israel implied 'righteousness', understood as reciprocal truthfulness and reliability. God's commitment was therefore conditional; any disobedience undermined the relationship. It was also generally confined to Israel as the 'people of God'.

2. The notion of the king as the representative of God was a firmly established Israelite-Jewish tradition with roots in the Ancient Near East. All the titles applied to Jesus in the New Testament were royal titles ${ }^{23}$ : 'Son of God' (Ps 2); 'Son of David' (e.g. 1 Ki 13:2 among many others); 'Son of Man' (Dn 7); the 'Anointed' (Mashiach; Christos); probably also the 'Image of God' (Gn 1:26-27). ${ }^{24}$ However, in contrast to the appropriation of the royal tradition, Jesus clearly did not reflect Jewish messianic expectations.

Jesus' interpretation of the God of Israel as a God of unconditional, suffering and redeeming love undermined the understanding of the Mosaic Law and its institutional entrenchments as the only valid foundation of Israelite God consciousness among the Jewish leaders of the time. And the real or assumed messianic pretensions of Jesus potentially threatened the authority of the Roman Empire and the Sanhedrin which operated as a Roman dependency.

In terms of evolutionary theory, therefore, the God consciousness of Jesus was not an entirely new emergent reality, nor a bifurcation, but the realisation of a preadaptation present in Jewish history that flourished in a specific environmental niche. That there were such niches is borne out by the fact that according to the Gospels Jesus had

23. With the exception of the Letter to the Hebrews, Jesus was not seen as a priest With rare exceptions, he was also not seen as a prophet.

24.In the Old Testament, the concept 'image of God' is found only in Genesis 1. It may be a Jewish response to the notion of the Babylonian myth of creation (the enuma elish), which defined the (common) human being as a slave of the gods (thus the aristocracy). If so, it claimed that all humans, male and female, were royalty, aristocracy). If so, it claimed that all humans, male and female, were royalty, God's creation. Paul applied the title to Christ, and by implication, to the believers in Christ, in 2 Corinthians 3:17-18 and 4:4-6. Here it denotes authentic humanity, in contrast to the inauthentic humanity of Adam, the fallen human being. a substantial following in Galilee and on his way to Jerusalem. Having been detached from the Jewish conditionality of God's acceptance, the message then spread rapidly in the pagan world.

\section{Christological implications of experiential realism}

According to the New Testament Jesus was the authorised representative of God, through whom God communicated 'his' unconditional benevolence first to 'his people' and then to humanity at large. That happened in the 'Christ-event', that is, his proclamation of the imminent 'kingdom of God', his redemptive action, his suffering and death on behalf of others, and his elevation to universal authority and accessibility, thus opening up the new authentic life of Christ in fellowship with God (God's 'righteousness') for all people at all times and in all situations.

All this presupposes that Jesus of Nazareth was a human being, no different from us, except that he was 'without sin', thus living and acting in undisturbed fellowship with the 'Father'. In terms of the Israelite-Jewish traditions, to attribute divine qualities to any earthly reality, let alone a human being, would be considered gross idolatry. ${ }^{25}$ Jesus of Nazareth never claimed to be God 'as such'. Nor did his immediate followers come to that conclusion.

He was seen, rather, as the true human being (the Messiah) in whom the true God manifested 'his' creative power and 'his' benevolent intentionality. ${ }^{26}$ This self-disclosure of God in Jesus of Nazareth was part of an ongoing human story, with earthly antecedents and consequences and as such part of the evolutionary history of the universe, rather than an eternal truth having dropped 'vertically from above' ${ }^{27}$

The Christ-event was the culmination of the 'covenant' history between Yahweh and Israel and continued in the relationship between the Spirit of Christ and the community of believers. The earth-bound character of what happened in Christ is critically important for our involvement in its dynamics, which is meant to be accessible to all humans. ${ }^{28}$ Being humans, we cannot become divine, but 'in Christ', the true human being, we can indeed become truly human.

The classical Christological doctrine makes no sense in ontological terms because (1) we know nothing of the 'ontology' of the transcendent God 'as such' and (2) ontology is an abstraction from the flow of immanent history and

25.This remains one of the most basic objections the Jewish and the Muslim faith levy against the Christian faith - and rightly so!

26.That is how Thomas' double statement 'my Lord and my God' in John 20:28 has to be understood. For the argument concerning the humanity of Jesus, see Nürnberger (2013:185-188).

27.This is the assumption of fundamentalist believers and, in another way, of Kar Barth's early 'dialectic theology', later modified considerably.

28. Note Paul's pervasive use of the idea that believers are 'in Christ', or members of the 'Body of Christ', or in the 'Spirit', rather than the 'flesh'. 
abstractions are not real. ${ }^{29}$ Formulated in terms of intentionality and agency, however, the doctrine makes immediate sense. To use a metaphor, the trumpet player and the trumpet both produce $100 \%$ (not $50 \%$ each) of the music and both retain their identity and integrity. ${ }^{30}$

\section{Cosmic implications of the cross of Christ}

The proclamation that God acted redemptively in the crucifixion of 'his' messianic representative implies a sacrificial concept of God. In Christ, 'his' messianic representative, God exposed 'himself' to the inherent constraints and inevitabilities of the cosmic process as well as to the ignorance, 'wrong consciousness' and waywardness of the human being. The cross does not represent a human sacrifice to an irate Deity, as much of conventional spirituality holds, but a divine sacrifice to an errant humanity.

Seen in this light, the crucifixion was a paradigmatic event that mirrors what can be observed in all of reality. The most pervasive example is the dialectical relation between evolutionary construction and entropic dissolution, life and death, freedom and error. Using anthropomorphic metaphors, entropy is the price God pays (and we have to pay) for having evolution in the first place; death is the price God pays (and we have to pay) for having life in the first place; depravity is the price God pays (and we have to pay) for having free will in the first place. ${ }^{31}$

God's suffering, transforming acceptance of the unacceptable is, therefore, not applicable only at the spiritual level of emergence, but across the cosmic process as a whole. It is clear that this kind of view has immediate implications for the economic and ecological crises that are fast approaching an unsuspecting, narcissistic and indifferent humanity. Humans are meant to share God's sacrificial love to make life possible for other humans and other creatures living with us and after we have left the scene.

29. Evolutionary theory tells us that reality is in flux and cannot be pinned down to a static 'being' without losing its vibrancy and relevance. Identity cannot be based on ontology, therefore, but has to be perceived as the dynamic continuity of an entity in the process of becoming.

30.The humanity of Jesus is fully acknowledged in the classical Christological doctrine The Council of Chalcedon (AD 451) declared that Christ encompassed, in one and the same person, a fully divine nature and a fully human nature, which should not be separated, but which should also not be confused with each other. At the Sixth between God's will and the will of Jesus. In Christ both the divine will and the between God's will and the will of Jesus. In Christ both the divine will and the
human will remained absolutely intact, with the divine will acting through the human will remained absolutely intact, with the divine will acting through the
human will. To avoid the paradoxes that the ontological, rather than dynamic, formulations of the doctrine create, we should replace 'in the same person' with 'in the same personal encounter': the Creator acts in and through the actions of a creature that is open for such action. Both subjects retain their ontological integrity because they do not operate at the same level, thus in competition or cooperation with each other. The suggestion that Jesus had no 'ego' of his own (expressed with the notion of anhypostasis), but that the divine Logos took the place of his human ego (expressed with the notion of enhypostasis) falls into the same trap as the idea that Jesus had no will of his own. Both were rejected as heretical. The same is true for the Gnostic idea that Jesus was 'God himself' in human form, thus not really a full (bodily concrete) human being.

31.The experiential concept of God excludes the Platonic concept of divine perfection, which is an idealised abstraction from the experience of time, space and energy discrepancies. The reality that we experience and of which we are a part is mindboggling and awe-inspiring, but it is certainly not perfect. In the biblical literature 'perfection' mainly refers to the excellence of the Law and God's reliability in terms 'perfection' mainly refers to the excellence of the Law and God's reliability in terms
of the covenant. In general the biblical worldview is geared to dynamic transformation rather than static perfection.

\section{Revelation in experiential realist terms}

Any concrete content of consciousness, including God consciousness, is part of experienced reality because (1) it has concrete consequences in this world and (2) it has a physical infrastructure of synaptic networks located in the human brain. Yet God consciousness is located at the spiritual and the social levels of emergence and only there. One cannot very well speak of the God consciousness of a stone, a kidney, or a slug. However, there are multiple feedback loops right through the entire hierarchy of emergences (downward and upward causation).

God consciousness emerges as an aha-experience - a hitherto concealed 'truth' flashes up within a particular niche and prompts an existential response. This is true mutatis mutandis for any new insight, including scientific insight. If more generally accepted by a community, this 'truth' forms a tradition, thus a process of evolution and differentiation in response to changing needs and situations, thus in response to changing environmental niches.

'Revelation' is therefore continuous, yet specific in terms of time and space. Responding to the changing situations of a faith community, it is mutable, dynamic, and versatile, albeit to varying degrees. It can also deteriorate and decay or be displaced by competitors. In this sense it is not dissimilar to the sequence of scientific models that integrate new empirical findings, perspectives and approaches. ${ }^{32}$

This formal description of revelation says nothing about the quality of a particular God consciousness. At the biological level there is a difference between a snake, a rhino and a chimpanzee. At the level of consciousness, there is a difference between the God consciousness of Adolf Hitler, Mahatma Ghandi and Mother Theresa. God consciousness is highly differentiated. It can be superficial or profound. It can be truncated or comprehensive. It can have detrimental or beneficial consequences. These consequences may undergo exponential escalations depending on their sensitivity to initial conditions and subsequent challenges. ${ }^{33}$

Therefore the struggle for the truth cannot be suspended just as scientific exploration is a continuous critical confrontation with alternative insights and models. The current emphasis on scientific insight, technological mastery and economic growth at all costs for the sake of wealth, power, status and consumerist avarice is the most farreaching, frightening and urgent case in point in view of its economic and ecological repercussions.

32.The seminal work of Thomas Kuhn (1970) provides ample evidence for this fact but one should not speak of 'revolutions', because there is both continuity and discontinuity between shifting paradigms.

33. Such escalations can be observed, for instance, in exorbitant medieval status assumptions and genocidal conflicts, excesses in contemporary fundamentalist Islamic groups, or the commercialisation of all aspects of life in liberal capitalist modernity. 


\section{Revelation in theological terms}

If God is our name for the intuited, perceived or conceptualised transcendent wherefrom and whereto of the reality that we actually experience and that the sciences explore, God manifests 'his' creative power in the entire process beginning with the big bang and moving through its billions of evolving stages, levels and facets.

If God is the Source of all of reality, God can use, and indeed does use, evolutionary processes at the level of human consciousness to make 'his' creativity and intentionality known, albeit in highly problematic and provisional forms. In fact, there is no other way that revelation could reach human consciousness. Theology as a discipline arises from the fact that the appropriateness of these forms cannot be taken for granted.

Expressed in terms of the theory of emergence, God became a person for humans because humans are persons, but as the Source of all levels of emergence he must be much more than a person, just as humans are much more than persons. ${ }^{34}$ Today we have to spell out this comprehensive character of our God concept to include not only personal intentionality and agency, but also the constraints, regularities and contingencies that characterise evolving reality and that are also of God. ${ }^{35}$

God's benevolent intentionality is articulated in the 'Word of God', which functions in history as the redemptive response of God to changing human predicaments and depravities, thus leading to an evolutionary trajectory or tradition. The consciousness of a benevolent God has emerged and evolved in the Israelite religious tradition culminating in the Christevent. That is the 'objective' side of revelation.

The subjective dimension of revelation is the existential confrontation with the divine expectation and the divine gift of an authentic existence within a healthy life world, appropriated through participation in the new life of Christ in fellowship with God and moving towards God's vision of comprehensive optimal well-being. Both the 'objective' and the 'subjective' dimensions operate at the spiritual (personal and social) levels of emergence and are part of cosmic reality at those levels.

\section{The dual nature of revelation}

That God reveals 'his' creative power in 'his' creation has never been problematic from Old Testament times onwards. ${ }^{36}$

34.That is the root of the personal, even anthropomorphic God concept underlying most parts of the biblical witness, which attributes everything that exists and happens to the personal Source and Destiny of reality.

35.A miracle, for instance, is any unexpected, awe-inspiring event that makes us humble and grateful. It does not have to be thought of in terms of a divine suspension of the laws of nature, or the divine utilisation of undetermined situations. 'Knowing' the entire spectrum of potential futures, God can very well act creatively and redemptively through the regularities and contingencies that 'he' installed to structure the cosmic process. Tracy offers a helpful analysis in this regard (Tracy 2008:249-283), as does Wegter-McNelly in the same volume (Wegter-McNelly 2008:299-314).

36.In response to the crisis of the self-understanding of an overly optimistic and human centred Europe after World War I, the dialectical theology of Karl Barth and his followers denied and decried any hint of the revelation of God in experienced reality, including human observation and human rationality. Karl Barth later
As far as the operation of God's creative power is concerned, theologians must get their clues from the sciences because theologians cannot possibly know better. But God's benevolent intentionality cannot be recognised in existentially experienced or scientifically explored reality. It is proclaimed and believed, not observed and explained.

However, those persuaded that God's intentionality is benevolent, will endeavour to 'see' this benevolence in the ambiguous reality they experience. The urge of all living creatures to survive and prosper, which is programmed into their system by evolution, is most highly developed in human personhood. That is the experiential mainspring of the intuition that the Creator wants his creatures to live and prosper. The experience of what ought not to have become leads to an intuition or vision of what ought to become, as well as the hope or expectation that it might become.

The proclamation of the benevolent intentionality of the Source of reality as the final Destiny of reality leads to the expectation that it will become - which is the root of eschatological visions. However, visions are not predictions. They are not based on observation but on trust and dedication. They provide direction and motivation. They typically 'overshoot' what seems to be possible and probable, leading to an inner freedom from obstacles and constraints and a joyful thrust into the future, but they can also become thoroughly misleading and counterproductive.

\section{Trinitarian implications}

If God is taken seriously as the Source of the whole of reality, the assumption of the benevolent intentionality of this God has to be projected to cover the whole of reality, that is, all levels of emergence from beginning to end. ${ }^{37}$ However, this proclaimed and believed intentionality of God clashes with the observation and experience of a highly ambiguous reality - which faith attributes to the creative power of the same God (theodicy).

By necessity, therefore, faith is the stubborn resolve to sustain the assurance of divine benevolence in the face of all indications and experiences to the contrary as well as the existential commitment to become involved in God's comprehensive vision and redemptive action in all spheres of life.$^{38}$ Far from positing an ontological threefold subdivision within God, let alone three God's, as the critics allege, but the stubborn insistence of the Christian faith that there is only one God, the loving God manifest in Christ, in the face of all indications to the contrary. Figure 8 gives an indication of the relation between these two experiences in the faith of the community.

(footnote 36 continues...)

corrected his one-sided focus to some extent, but the theological basis of his argument presented a formidable obstacle to the task of integrating actual human observations and scientific insights in the Christian concept of God.

37.The application of God's intentionality to the cosmic process as a whole takes care of what has recently been called 'deep incarnation' and dealt with in this volume, but it does so without removing the inescapable ambiguity of this process.

38.As Luther expressed it, the Christian faith is a struggle with God against God. It is characterised by reassurance (Luther called it 'promise'), rather than certainty. It is always an afflicted faith; one can never catch hold of it; it must be proclaimed by an outside agent based on an outside source (verbum externum) and appropriated in outside agent based on an outside source (verbum externum) and appropriated in
constant conflict with the 'old self' of every human being (simul iustus et peccator). For detail, see Nürnberger (2011:223-228). 


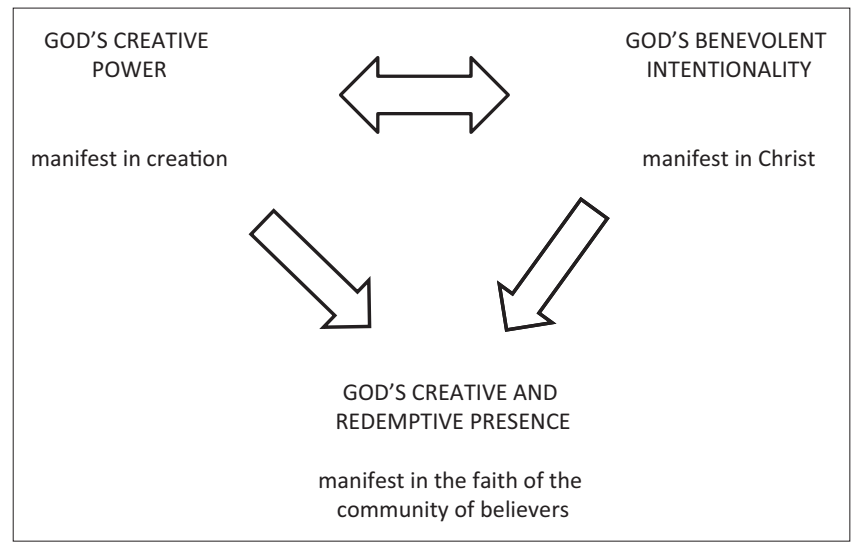

Source: Author's own work

FIGURE 8: The Trinity in experiential terms.

Properly understood, therefore, the doctrine of the Trinity is an expression of the existential tension between the two contradicting experiences (ambivalent creative power and unconditional benevolence) as it plays itself out in the personal and communal consciousness of the community of believers. It claims the God of experience for the God of faith. ${ }^{39}$ It must be expressed in dynamic, existential and situational terms, rather than in the form of ontological constructs. It should also not be abused as the point of departure for metaphysical speculations concerning the nature of 'God in himself', or 'God as such', about which we know nothing whatsoever. ${ }^{40}$

\section{Eschatological implications of experiential realism}

Eschatology is transcendence in terms of time. The theological postulates of an initial (protological) or eventual (eschatological) state of perfection are projections of what ought to become based on the experience of what not to have become. Any reification of these metaphorical or mythological expressions misses their true intentions. ${ }^{41}$

Formulated in experiential-realist terms, God's benevolence expresses itself as God's vision of comprehensive optimal well-being that translates into God's concern for any deficiency in well-being in any dimension of life. This vision and this concern are meant to be shared by those

39.The classical Trinitarian doctrine postulates that the Creator is the same God as the Redeemer and the Spirit of God; it also maintains that the 'works of the three persons of the Trinity in regard to the world are indivisible' (or indistinguishable). persons of the Trinity in regard to the world are indivisible' (or indistinguishable).
This postulate seems to deny the reality of an ambiguous creation, but it can be This postulate seems to deny the reality of an ambiguous creation, but it can be
understood as the attempt to claim the latter for the God of redeeming love in the face of contrary experience.

40.This concept of the Trinity is fully developed in Nürnberger (2016, Chapter 9: 291-327)

41.This is borne out by the fact that these narratives deliberately go beyond the manifest, the probable and the possible: creation of the female out of a body part of the male after no consort for the latter could be found among animals; thei deception by a snake who outwitted the human being; creation of a giant canopy to prevent the primeval ocean above the skies from flooding the space in which life was possible; creation of the sun after the plants had been created, with the sole purpose of distinguishing day from night; the vision of a new Jerusalem as a cube with dimensions greater than the distance from Johannesburg to Cape Town, made of pure gold but transparent like glass, and so on. When taking account of the linguistic nature of such narratives it becomes self-evident that they were never meant to be historical accounts, empirical descriptions or reliable predictions. who live in fellowship with a creative and benevolent God. ${ }^{42}$

The divine vision resembles a moving horizon that opens up ever new insights, challenges and opportunities. It affords meaning, acceptability and authority to be what we, and our life world, have become, and yet the expectation that we, and our life world, will be transformed into what we, and our life world, ought to become as an instrument of God's intentions.

The classical dualistic worldviews were also meant to contrast what had become with what ought to become whether Platonic in terms of an ideal (spiritual) space, or apocalyptic in terms of an ideal (future) time. As such they contained powerful calls to live authentic and responsible lives in the here and now.

However, the dualistic character of such formulations has become untenable in terms of the scientific worldview. The apocalyptic kind cannot account for the dialectic between evolution and entropy, life and death, construction and destruction. The Platonic type cannot account for the fact that the spiritual level of emergence depends on its subatomic, physical, biological and neurological infrastructure.

Theologically speaking, the apocalyptic type had a tendency to deprecate the here and now in favour of an idealised future, while the Platonic type deprecated the bodily concreteness of life in favour of a spiritual construct that could exist and flourish without its physical, biological and neurological infrastructure.

The result has been that they shifted the responsibility of believers for the maintenance and transformation of their life worlds to a God who would fix the cosmos once and for all in 'his good time' and all by 'himself' in 'his' supreme sovereignty. Such approaches can easily paralyse the creative and motivational capacity of the human being, rather than arousing and empowering it, thus depriving humans of a life lived fully here and now while it lasts.

\section{Conclusion}

With that I hope to have presented a concept of revelation that is based solidly on the principle of experiential realism, avoids assumptions of a 'supernatural' factor or agent within immanent reality and does not clash with scientific core assumptions - provided science does not entertain a naturalistic reductionism that decrees that there is no transcendent Source and Destiny of reality as such and as a whole and that the world we experience is all there is. The naturalist assumption is not a scientific finding, but a metaphysical postulate, which the Christian faith cannot entertain without losing its foundations.

42. For a full development of the argument, see Nürnberger (2011:216-246, 2016:459-518). 


\section{Acknowledgements Competing interests}

The author declares that he has no financial or personal relationships which may have inappropriately influenced him in writing this article.

\section{References}

Clayton, P., 2006, Mind and emergence: From quantum to consciousness, Oxford University Press, Oxford. (Originally published 2004)

Drees, E.B., 1990, Beyond the big bang, Quantum cosmologies and God, Open Court, La Salle, IL.

Ellis, G., 2008, 'Scientific issues: Ground covered and horizons unfolding', in R.J. Russel, N. Murphy \& W.R. Stoeger (eds.), Scientific perspective on divine action: Twenty years of challenge and progress, pp. 57-82, Vatican Observatory Twenty years of chall

Greene, B., 2005, The fabric of the cosmos: Space, time, and the texture of reality, Vintage Books, New York.

Gregersen, N.H. 2008, 'Special divine action and the quilt of laws: Why the distinction between special and general divine action cannot be maintained', in R.J. Russel, N Murphy \& W.R. Stoeger (eds.) Scientific perspective on divine action: Twenty years
of challenge and progress, pp. 179-199, Vatican Observatory Publications, of challeng

Hawking, S. \& Mlodinow, L., 2010, The grand design: New answers to the ultimate questions of life, Bantam Press, London.

Kauffman, S., 2008, Reinventing the sacred: A new view of science, reason and religion, Basic Books, New York.

Kuhn, T.S., 1970, The structure of scientific revolutions, 2nd edn., University of Chicago Press, Chicago, IL.

Mitchell, M., 2009, Complexity: A guided tour, Oxford University Press, Oxford

Nürnberger, K., 1999, Prosperity, poverty and pollution: Managing the approaching crisis, Cluster Publications, Pietermaritzburg.
Nürnberger, K., 2002, Theology of the biblical witness: An evolutionary approach, LITVerlag, Münster, Germany.

Nürnberger, K., 2011, Regaining sanity for the earth: Why science needs best faith to be responsible, why faith needs best science to be credible, Cluster Publications, Pietermaritzburg.

Nürnberger, K., 2012, 'Eschatology and entropy: An alternative to Robert John Russell's proposal', Zygon 47(4), 970-996.

Nürnberger, K., 2013, Informed by science, involved by Christ: How science can update, enrich and empower the Christian faith, Xlibris Corporation, London.

Nürnberger, K., 2016. Faith in Christ today: Invitation to systematic theology, vol. II, Cluster Publications, Pietermaritzburg.

Peacocke, A., 2007, All that is: A naturalistic faith for the twenty-first century, P. Clayton, (ed.), Fortress Press, Minneapolis, MN.

Polkinghorne, J. 1996, Scientists as theologians, SPCK, London.

Russell, R.J. 2008, Cosmology from alpha to omega: The creative and mutual interaction of theology and science, Fortress Press, Minneapolis, MN.

Russell, R.J., Murphy, N. \& Stoeger, W. (eds.), 2008, Scientific perspective on divine action: Twenty years of challenge and progress, Vatican Observatory Publications, Vatican.

Smail, D.L., 2008, On deep history and the brain, University of California Press, Berkeley, CA.

Tappert, T.G., 1959, The book of concord: The confessions of the Evangelical Lutheran Church. Fortress Press, Philadelphia, PA. (Originally published 1580)

Tracy, T.F., 2008, 'Special Divine Action and the Laws of Nature', in R.R. Russell, N. Murphey \& W.R. Stoeger (eds), Scientific Perspectives on Divine Action: Twenty Years of Challenge and Progress, pp. 249-283, Vatican Observatory Publications, Vatican City State / The Center for Theology and the Natural Sciences, Berkeley, CA.

Wikipedia, 2016, 'Chaos theory', viewed n.d., from https://en.wikipedia.org/wiki/ Chaos_theory

Wikipedia, 2016, 'Neuron', viewed n.d., from https://en.wikipedia.org/wiki/Neuron

Wikipedia, 2016, 'Synapse', viewed n.d., from https://en.wikipedia.org/wiki/Synapse

Wegter-McNelly, K., 2008, 'Does God need room to act? Theo-physical in/contapitilism in noninterventionist theories of objectively special divine action', in R.J. Russel, N. Murphy \& W.R. Stoeger (eds.), Scientific perspective on divine action: Twenty years of challenge and progress, pp. 299-314, Vatican Observatory Publications, Vatican. 